\title{
Controlled-Release Fertiliser and Substrates on Seedling Growth and Quality in Agonandra brasiliensis in Roraima
}

\author{
Aline das Graças Souza (Corresponding Author) \\ Department of Fitotecnia and Environmental Sciences, Federal University of Paraíba, \\ Campus II/Areia-PB. Brasil. E-mail: alineufla@hotmail.com
}

Oscar José Smiderle

Brazilian Agricultural Research Corporation - Embrapa Roraima, Boa Vista-RR, Brazil.

E-mail: oscar.smiderle@embrapa.br

\section{Raiovane Araújo Montenegro}

Federal University of Roraima, UFRR, Campus Cauamé, BR 174, Km 12, Monte Cristo, Boa Vista, RR, Brazil. E-mail:raiovane@hotmail.com.br

Thiago Komuro Moriyama

Federal University of Roraima, UFRR, Campus Cauamé, BR 174, Km 12, Monte Cristo, Boa Vista, RR, Brazil. E-mail: thiago.tkm@hotmail.com

Thiago Jardelino Dias

Department of Agriculture, Federal University of Paraíba, Campus III/Bananeiras-PB, Brasil. E-mail: thiagojardelinodias@gmail.com

Received: Dec. 23, 2019 Accepted: Jan. 19, $2020 \quad$ Published: Jan. 20, 2020

doi:10.5296/jas.v8i3.16363 URL: https://doi.org/10.5296/jas.v8i3.16363

\begin{abstract}
The aim of this study was to verify the effect of different substrates, in the presence and absence of controlled-release fertiliser, on the growth and morphological quality of seedlings of Agonandra brasiliensis Miers ex Benth. \& Hook.f., in the state of Roraima, Brazil. The experimental design was a 2 x 5 factorial scheme, with and without the addition of $1.0 \mathrm{~g} \mathrm{~L}^{-1}$ NPK 18-05-09 formulation controlled-release encapsulated fertiliser (Forth Cote ${ }^{\circledR}$ ) and five substrates. The following were evaluated: shoot height $(\mathrm{H})$, collar diameter $(\mathrm{CD})$, increase in
\end{abstract}


shoot length (IncH) and collar diameter (IncCD), shoot dry weight (SDW), root dry weight (RDW), total dry weight (TDW) and Dickson quality index (DQI). The use of NPK 18-05-09 formulation controlled-release fertiliser (Forth Cote ${ }^{\circledR}$ ) in a medium-sand substrate is recommended for obtaining plants of Agonandra brasiliensis of greater robustness, balance of biomass distribution, and a high standard of quality. In the substrate composed of soil from the cerrado + carbonised rice husks - CRH + organic substrate $(2: 1: 1)$, the addition of NPK 18-05-09 formulation Forth Cote ${ }^{\circledR}$ is not necessary to obtain Agonandra brasiliensis plants of good morphological quality. Substrate 3, composed of soil + CRH (3:1), with or without the addition of NPK 18-05-09 formulation Forth Cote $^{\circledR}$, is not recommended for producing plants of Agonandra brasiliensis, due to the slow development and reduced morphological quality of the plants.

Keywords: opiliaceae, native forest species, plant nutrition, forth cote ${ }^{\circledR}$

\section{Introduction}

Opiliaceae Valeton is a small pantropical family with centres of diversity in Southeast Asia and Oceania. In Brazil, Opiliaceae is represented only by the genus Agonandra Miers ex Benth. \& Hook.f., which includes 10 species, distributed from Mexico to northern Argentina. Five species and one subspecies occur in Brazil across all the phytogeographical domains, except the Pampas (CNI, 2017). Only one species, Agonandra brasiliensis Miers ex Benth. \& Hook.f., has been registered in the state of Roraima (Souza and Lorenzi, 2012). It is considered one of the noble trees of the Roraima cerrado, as it provides good quality wood. In addition, it is regarded as an ornamental tree, and is planted in squares and parks.

Considering that Agonandra brasiliensis represents one of the species in the Roraima cerrado having both economic and environmental potential, there is a need to adopt incentive programs for the conservation and propagation of the species (Ramalho and Zappi, 2017).

However, there is little information on the species, especially from studies aimed at establishing protocols for seedling production which may serve as an aid to investment in this sector.

Quality seedlings are essential to ensure the success of revegetation, germplasm rescue and the establishment of settlements, whether for commercial or conservation purposes (Holland et al., 2019). For this, it is necessary to use substrates of suitable chemical characteristics, which would maximise seedling growth, allowing good formation of the root system and shoots (Bich et al., 2019).

There are several materials that can be used, either singly or combined, as substrates to produce seedlings of forest species, such as sand, soil, expanded clay, vermiculite, sawdust, rice husks and coconut-shell fibre, among others (Souza et al., 2018). A good substrate with proper handling should be used, together with a quality fertiliser in suitable doses. According to Messa et al. (2016), Forth Cote ${ }^{\circledR}$, a controlled-release nutrient fertiliser, is often used to produce seedlings in containers.

Menegatti et al. (2017) report that controlled-release fertiliser provides nutrients to the seedlings continuously and for a longer period, which results in less possibility of nutrient deficiency during the period of seedling formation, dispensing with the split application of 


\section{Macrothink}

other sources, thereby reducing the operating costs of seedling production.

Given the above, the aim of this study was to verify the effect of different substrates, in the presence and absence of controlled-release fertiliser, on the development and morphological quality of seedlings of Agonandra brasiliensis in the state of Roraima (RR), Brazil.

\section{Material and Methods}

The experiment was conducted under 50\% shade in a nursery of Embrapa Roraima, located in Boa Vista, RR. The species used in the research was Agonandra brasiliensis Miers ex Benth \& Hook. The seeds came from fruit of Agonandra brasiliensis collected from the trees of a single producer (Figure 1) in the town of Caracaraí (RR), Brazil in March 2018.
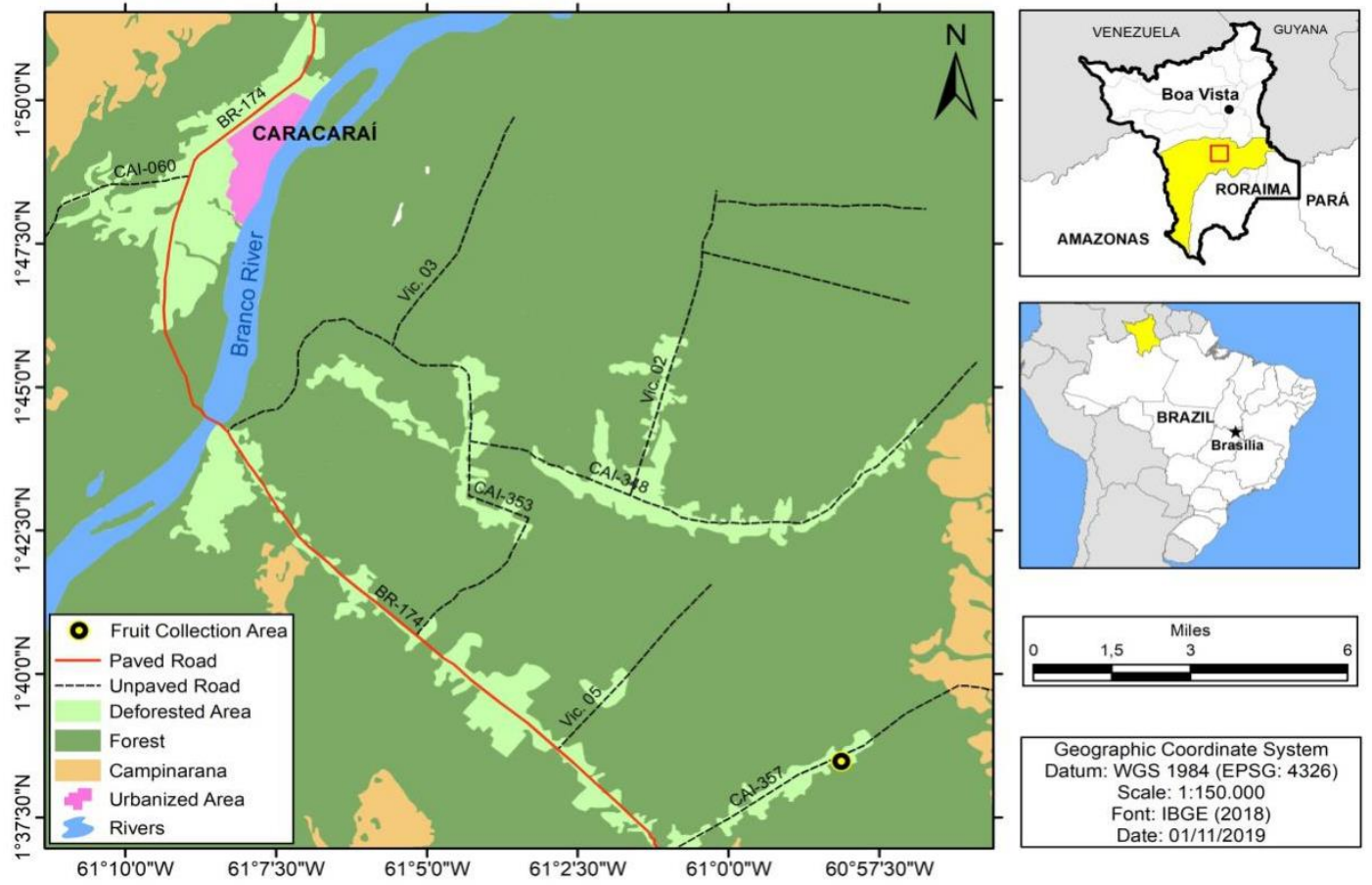

Figure 1. Location of the sampled trees of Agonandra brasiliensis in the town of Caracaraí (RR), March 2018

After collection, the fruit was taken to the seed laboratory of EMBRAPA-RR (Empresa Brasileira de Pesquisa Agropecuária). The seeds were processed, and then sown in a seed-bed with washed medium-sand as a substrate for germination and initial seedling growth. The moisture of the medium-sand substrate was maintained under scheduled irrigation by sprinkler every four hours during the day, with each irrigation lasting five minutes.

Forty days after sowing, as soon as they had reached a homogeneous height of approximately $10.0 \mathrm{~cm}$, the seeds were transplanted into 2.2-L polyethylene bags containing different combinations of substrate: (Sub 1) - Medium sand; (Sub 2) - Soil from the cerrado (Red-Yellow Latosol) + Carbonised Rice Husks (CRH + Organic Substrate (OS) (2:1:1); (Sub 3) - soil + CRH (3:1); (Sub 4) - soil + sand + CRH + OS (3:1:1:1); and, (Sub 5) - Sand + $\mathrm{CRH}+\mathrm{OS}(2: 1: 1)$.

The effect of the absence or presence of NPK 18-05-09 formulation controlled-release encapsulated fertiliser (Forth Cote ${ }^{\circledR}$ ) was evaluated for each substrate on the growth and 
development of the plants of Agonandra brasiliensis. Forth Cote ${ }^{\circledR}$ contains macronutrients which are coated in a membrane to allow for slow delivery over three to four months, and a guaranteed content of $18 \%$ total nitrogen $(\mathrm{N}), 05 \%$ phosphorus $\left(\mathrm{P}_{2} \mathrm{O}_{5}\right)$ and $09 \%$ potassium $\left(\mathrm{K}_{2} \mathrm{O}\right)$.

The experimental design was a 2 x 5 factorial scheme, with and without the addition of $1.0 \mathrm{~g}$ $\mathrm{dm}^{-3}$ NPK 18-05-09 formulation controlled-release encapsulated fertiliser (Forth Cote ${ }^{\circledR}$ ), and five substrates, with five replications, each replication comprising five seedlings (one in each container). A graduated beaker with a capacity of $1,000 \mathrm{~mL}$ was used to measure the necessary volume of each component making up the substrates. After each substrate was homogenised, samples from each treatment were separated for later chemical and physical analysis.

The Embrapa (2009) method was used for the chemical analysis to determine the available macronutrient content, $\mathrm{pH}$, exchangeable aluminum (Al), titratable acidity $(\mathrm{H}+\mathrm{Al})$ and cation exchange capacity at $\mathrm{pH} 7$ (CEC) of each substrate used.

Table 1. Chemical composition of the different combinations of soil, organic substrate, rice husks and sand used to grow seedlings of Agonandra brasiliensis under nursery conditions, Boa Vista, RR, Brazil

\begin{tabular}{|c|c|c|c|c|c|c|c|c|c|c|c|c|c|c|}
\hline \multirow{2}{*}{ Sub } & \multirow{2}{*}{$\mathrm{pH}$} & $\mathrm{K}$ & $\mathrm{P}$ & $\mathrm{Ca}$ & $\mathrm{Mg}$ & $\mathrm{Al} \mathrm{H}$ & $\mathrm{H}+\mathrm{Al}$ & M.O. & $\mathrm{Zn}$ & E。 & $\mathrm{Mn}$ & $\mathrm{Cu}$ & B & S \\
\hline & & \multicolumn{13}{|c|}{ 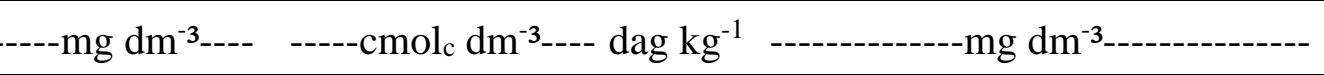 } \\
\hline 1 & 5.7 & 0.89 & 0.27 & 0.10 & 0.1 & 0.1 & & & 1.1 & & 5.21 & 0.1 & 0.1 & 0.50 \\
\hline 4 & 5.2 & 5.85 & 11.2 & 8.14 & 0.8 & 0.1 & 10 & 5.45 & 7.9 & 50.2 & 49.0 & 0.9 & 0.3 & 2.63 \\
\hline 5 & 5.1 & 5.47 & 11.2 & 4.21 & 0.3 & 0.1 & 1.7 & 5.38 & 19.6 & 31.9 & 57.9 & 0.4 & 0.2 & 2.49 \\
\hline 7 & 5.6 & 6.84 & 13.7 & 3.67 & 0.4 & 0.1 & 2.3 & 5.31 & 12.9 & 42. & 149.2 & 1.6 & 0.2 & 2.42 \\
\hline 8 & 4.8 & 2.47 & 9.8 & 2.63 & 0.3 & 0.1 & 2.9 & 5.17 & 16.8 & 31.5 & 69.6 & 0.8 & 0.1 & 1.35 \\
\hline
\end{tabular}

*Sub 1- Medium sand; Sub 2 - Soil from the cerrrado (Red-Yellow Latosol) + carbonised rice husks - CRH + organic substrate (2:1:1); (Sub 3) - Soil + CRH (3:1); (Sub 4) - Soil + sand + CRH + OS (3:1:1:1); (Sub 5) - Sand + CRH + OS (2:1:1).

To evaluate the experiment, the morphological characteristics of the Agonandra brasiliensis plants were quantified: Shoot growth or height $(\mathrm{H}, \mathrm{cm})$, was measured with the aid of a graduated rule; collar diameter $(\mathrm{CD}, \mathrm{mm})$ was measured with a digital calliper; the increase in shoot length $(\mathrm{IncH}, \mathrm{cm})$ and collar diameter $(\mathrm{IncCD}, \mathrm{mm})$ were obtained from data collected every thirty days (month) following transplantation, throughout the period of plant growth until the end of the experiment (six months).

Other variables under evaluation were the root and shoot dry weight. The roots were washed in running water to remove the substrate, and the roots and shoots then packed in paper bags and placed in a drying oven at $70^{\circ} \mathrm{C}$ for 72 hours. After drying, the samples were weighed on a $0.01 \mathrm{~g}$ precision balance to determine shoot dry weight (SDW, g per plant) and root-system dry weight (RDW, g per plant); from the sum these two, the total dry weight of the plant (TDW) was calculated.

These parameters were transformed into indices as suggested by Gomes et al. (2002): H/CD, 


\section{MIMacrothink}

H/SDW, SDW/ RDW. To measure the quality of the seedlings to be used, the Dickson Quality Index (DQI) was used as reference, employing the formula proposed by Dickson et al. (1960).

$$
\mathrm{IQD}=\frac{\mathrm{MST}_{(\mathrm{g})}}{\mathrm{H}_{(\mathrm{cm})} / \mathrm{DC}_{(\mathrm{mm})}+\mathrm{MSPA}_{(\mathrm{g})} / \mathrm{MSR}_{(\mathrm{g})}}
$$

where TDW $(\mathrm{g})=$ total dry weight $\mathrm{H}(\mathrm{cm})=$ Shoot height $\mathrm{CD}(\mathrm{mm})=$ collar diameter; SDW (g per plant $)=$ shoot dry weight; RDW $(\mathrm{g}$ per plant $)=$ root-system dry weight.

The mean values of the variables were submitted to statistical analysis using the Sisvar software (Ferreira, 2011), employing analysis of variance and regression for the time factor (days), and Tukey's test at 5\% probability to compare the mean values of the other variables.

\section{Results}

All the variables under analysis showed an interaction $(\mathrm{p}<0.05)$ between the substrate and the absence or presence of SRF (Forth Cote ${ }^{\circledR}$ ), indicating that the study of factor interaction is important for defining the best substrate to stimulate plant growth, with and without fertiliser.

Height was $38.0 \mathrm{~cm}$ for the plants of Agonandra brasiliensis grown in substrate Sub 4 (Sand + CRH + OS (2:1:1)) in the presence of SRF (Forth Cote ${ }^{\circledR}$ ), with an increase greater than twice the height of treatment Sub 1 (medium-sand) without the addition of SRF (Forth Cote ${ }^{\circledR}$ ) for the same environment, six months after transplanting (Figure 2).
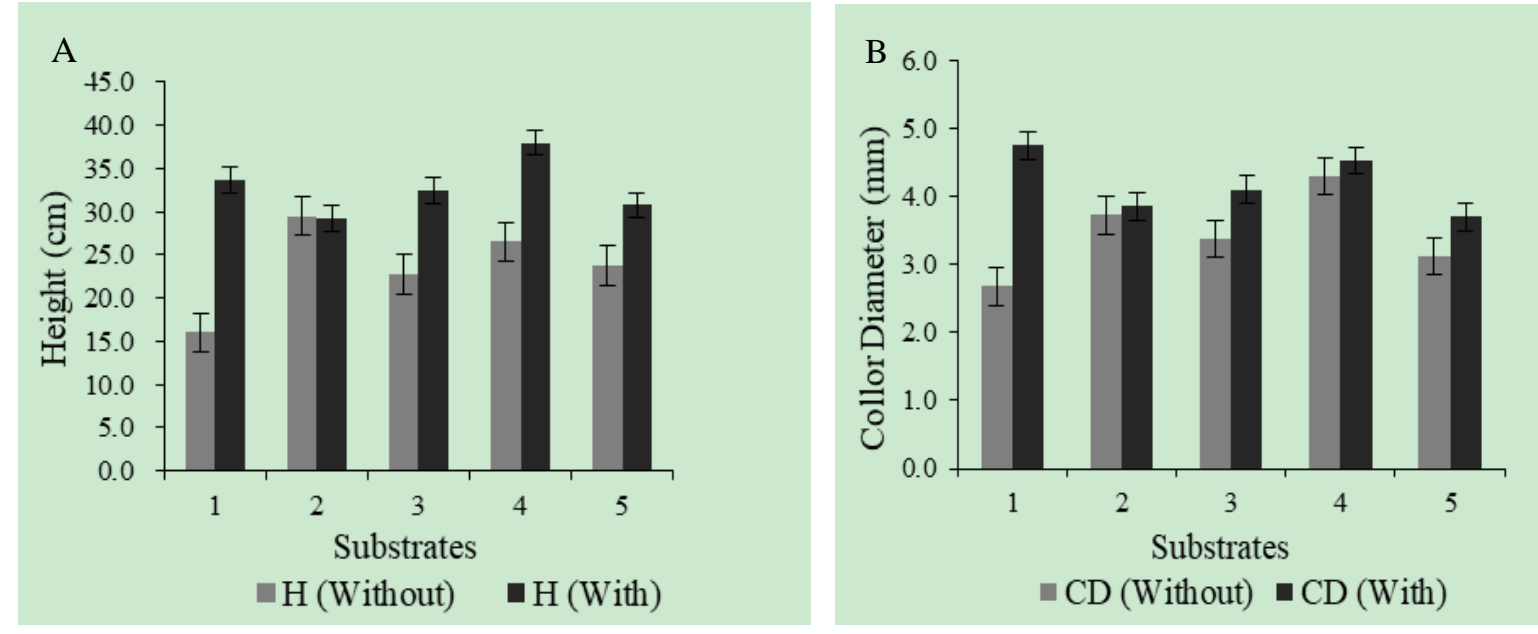

Figure 2. Height (A) and collar diameter (B) in plants of Agonandra brasiliensis in different substrates: (Sub 1) - Medium sand; (Sub 2) - Soil from the cerrado + Carbonized Rice Husks - CRH + Organic Substrate (2:1:1); (Sub 3) - Soil + CRH (3: 1); (Sub 4) - Soil + Sand + CRH + OS (3:1:1:1); and, (Sub 5) - Sand + CRH + OS (2:1:1) with and without the addition of controlled-release encapsulated fertiliser (Forth Cote ${ }^{\circledR}$ ) under nursery conditions, six months after transplanting

When analysing the height of plants grown in substrate 2 with and without the addition of SRF, similar results were found for this variable (Figure 2A), unlike for Sub 4 with added SRF, which showed a further $30 \%$ gain in height when compared to the same substrate but without the added SRF (Figure 2A). However, when analysing collar diameter, substrate 3 showed similar behaviour to the results obtained for plant height, i.e. inferring that there was no effect from the SRF on collar-diameter size (Figure 2B). 


\section{$\triangle$ Macrothink}

The collar diameter in the Agonandra brasiliensis plants in substrate 2 was $3.90 \mathrm{~mm}$ with the addition of SRF, and $3.70 \mathrm{~mm}$ without the added SRF (Figure 2B). This was also seen for collar diameter in substrate 4 with or without the addition of SRF (Figure 2B), as such, it is not necessary to add fertiliser in the production of seedlings of Agonandra brasiliensis.

It is worth noting that substrate 1 with the addition of SRF stood out in promoting the thickness and greater precocity of the collar diameter $(4.8 \mathrm{~mm})$ when compared to the other substrates, with or without the addition of SRF (Figure 2B) at 240 DAT in the screened nursery.

Regarding the increase in height (Figure 3A), for the five substrates with and without the addition of SRF, it was found that the plants of Agonandra brasiliensis produced in Sub 4 with added SRF showed an increase of $20.75 \mathrm{~cm}$, while the mean increase for both Sub 2 and Sub 5 with added SRF was approximately $14.0 \mathrm{~cm}$.
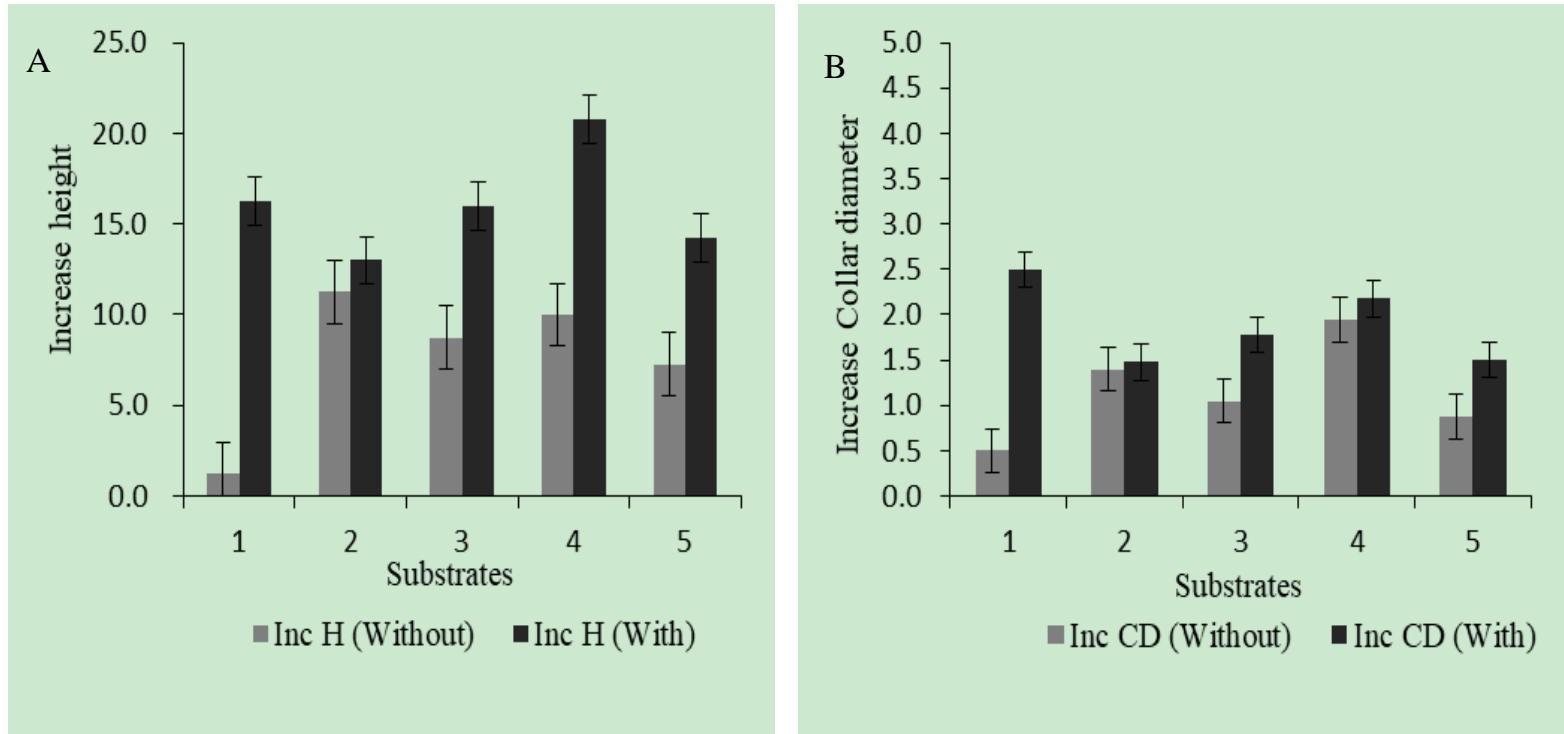

Figure 3. Increase in height (A) and collar diameter (B) in plants of Agonandra brasiliensis in different substrates: (Sub 1) - Medium sand; (Sub 2) - Soil from the cerrado + Carbonized Rice Husks - CRH + Organic Substrate (2:1:1); (Sub 3) - Soil + CRH (3: 1); (Sub 4) - Soil + Sand + CRH + OS (3:1:1:1); and, (Sub 5) - Sand + CRH + OS (2:1:1) with and without the addition of controlled-release encapsulated fertiliser (Forth Cote ${ }^{\circledR}$ ) under nursery conditions,

six months after transplanting

In Sub 1 with the addition of SRF, the mean increase in height was similar to Sub 3 (Figure 3A). Different responses for the increase in collar diameter were found (Figure 3B), which in Sub 1 with the addition of SRF was approximately $2.5 \mathrm{~mm}$. However, comparing treatments with and without the addition of SRF to Sub 1, the difference in the increase in collar diameter was approximately $15.0 \mathrm{~mm}$ (Figure 3B). Shoot dry weight (SDW) in the Agonandra brasiliensis seedlings showed a gain of approximately $80 \%$ from the addition of SRF in substrate Sub 1, compared to Sub 1 without the addition of SRF (Figure 4A). This trend was also seen for Sub 3, with an increase of $67.7 \%$ between the treatments with and without added SRF (Figure 4A).

In addition, Sub 5 showed less production of root-system dry weight (RDW, g per plant), both with and without the addition of SRF (Figure 4B). However, plants of Agonandra 


\section{Macrothink}

brasiliensis grown in Sub 2, with and without added SRF, showed similar results for root dry weight (Figure 4B).
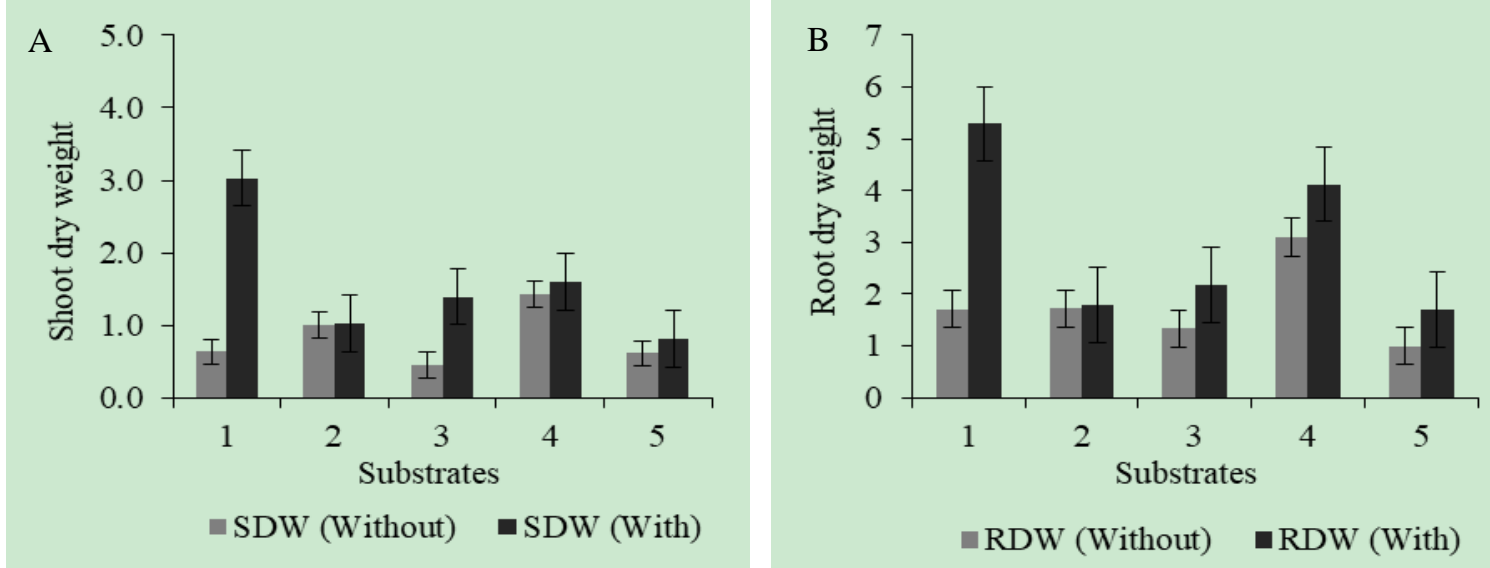

Figure 4. Shoot dry weight (g per plant) (A) and root dry weight (g per plant) (B) in plants of Agonandra brasiliensis in different substrates: (Sub 1) - Medium sand; (Sub 2) - Soil from the cerrado + Carbonized Rice Husks - CRH + Organic Substrate (2:1:1); (Sub 3) - Soil + CRH (3: 1); (Sub 4) - Soil + Sand + CRH + OS (3:1:1:1); and, (Sub 5) - Sand + CRH + OS

(2:1:1) with and without the addition of controlled-release encapsulated fertiliser (Forth Cote $^{\circledR}$ ) under nursery conditions, six months after transplanting

The results obtained in the present study demonstrated that the use of Sub 4 with added SRF gave an increase of $7.0 \%$ in root dry weight when compared to Sub 3 without added SRF at 240 DAT (Figure 4B).

The results once again show the positive effect of adding SRF to the substrate on the production of total dry weight (Figure 5A), with particular emphasis on Sub 1 (Medium sand).
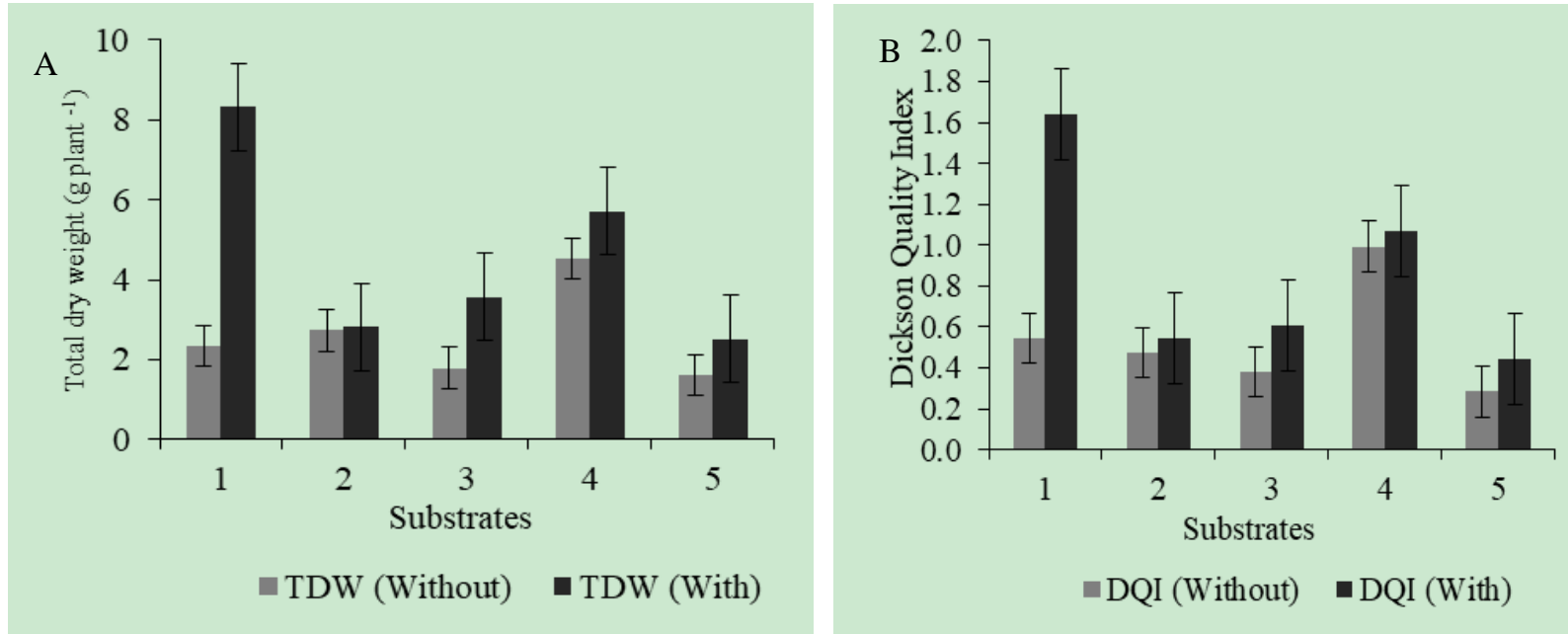

Figure 5. Total plant dry weight (A) and Dickson Quality Index (B), in plants of Agonandra brasiliensis in different substrates: (Sub 1) - Medium sand; (Sub 2) - Soil from the cerrado + Carbonized Rice Husks - CRH + Organic Substrate (2:1:1); (Sub 3) - Soil + CRH (3: 1); (Sub 
4) - Soil + Sand + CRH + OS (3:1:1:1); and, (Sub 5) - Sand + CRH + OS (2:1:1) with and without the addition of controlled-release encapsulated fertiliser (Forth Cote ${ }^{\circledR}$ ) under nursery conditions, six months after transplanting

It should also be noted that the Dickson quality index for Agonandra brasiliensis plants grown in substrate 1 with the addition of SRF (Figure $5 \mathrm{~B}$ ) presented a greater mean value, the plants being considered superior with greater growth balance and nutritional quality. Similarities were found between the treatments, comparing the quality of the Agonandra brasiliensis plants grown in substrate 4 with and without added SRF (Figure 5B), making the unit cost per seedling attractive due to the possibility of reducing costs through the use of this input. Substrates 2, 3 and 5, with and without the addition of SRF, did not reach the minimum value for the quality index, which according to Souza et al. (2018), is equal to or greater than 1 for forest species.

\section{Discussion}

The results suggest that plants grown in Sub 1 and Sub 5 with SRF added to the substrates showed precocious plant height and collar diameter, this may be a result of the greater amount of available nutrients, both at the moment of greatest nutritional need after transplanting, and throughout the growth of the plants.

It is worth noting that substrate 1 without the addition of SRF, consisting entirely of medium sand, can be described as a substrate devoid of mineral nutrients (Table 1), which may have compromised growth and development (Figures 1A and B) in the Agonandra brasiliensis plants due to the low production of enzymes, proteins, carbohydrates and other compounds indispensable to plant metabolism.

Shoot height is an easily measured variable, and is commonly used to estimate the quality and robustness of plants. Therefore, substrates that afford superiority for this characteristic offer greater efficiency in capturing solar energy and, consequently, help in maintaining satisfactory rates of photosynthesis as an aid to biomass production and plant growth (Taiz et al., 2017).

It is also worth pointing out that the increase in macronutrient content (NPK) obtained by adding the NPK 18-05-09 formulation SRF (Forth Cote ${ }^{\circledR}$ ) to the medium-sand substrate caused an improvement in cation exchange capacity (CEC), which is responsible for the retention and prolongation of nutrient availability throughout the period of plant growth, ensuring that the fertility of the substrate be maintained.

According to Table 1, it was found that substrates 1 and 4 presented a $\mathrm{pH}$ value within the range considered appropriate for plant development (5.5 to 6.5) as per the classification described by Menegatti et al. (2019). The remaining substrates under test presented $\mathrm{pH}$ values lower than those considered satisfactory.

The $\mathrm{pH}$ value is an extremely important chemical characteristic, as it is directly related to the availability of nutrients to the plants; as such, inappropriate values can affect plant growth and development, especially in substrates with a $\mathrm{pH}$ of less than 5 (Fermino, 2014), as seen in the Agonandra brasiliensis plants in substrate 5 (Figures 1, 2, 3, 4A and B), with a pH of 4.8 (Table 1).

In turn, the K content of the NPK 18-05-09 formulation SRF (Forth Cote ${ }^{\circledR}$ ) added to substrate 1 directly influenced the higher mean collar diameter, since, according to D'Avila et al. (2011) and Silva et al. (1997), in more than 14 forest species, $\mathrm{K}$ is an element that is capable of 
promoting high levels of water retention in plant tissue, which induces greater cell turgor and results in greater thickening of the stem.

This was also seen in plants of Tectona grandis grown in substrates formulated with biosolids, in which Trazzi et al. (2014) found that growth in diameter is directly related to the levels of K.

Smiderle and Souza (2016), studying the effect of potassium on the quality of Cinnamomum zeylanicum seedlings, concluded that the species has a high demand for $\mathrm{K}$, and that the use of potassium fertiliser should be considered a strategy for favouring the production of high-quality seedlings over a shorter period.

Another relevant characteristic were the greater increases in both height and diameter in substrates 1 and 4 with the addition of SRF. A similar response, describing increases in height and diameter with the application of Osmocote ${ }^{\circledR}$, was seen in works by Dutra et al. (2016) on the growth of Peltophorum dubium seedlings in different environments.

In practical terms, the greater production of RDW shown by Agonandra brasiliensis plants in substrate 1 with the addition of SRF (Figure $3 \mathrm{~B}$ ) probably promoted the production and maintenance of root systems with greater expansion, resulting in the exploitation of a larger area of soil and, consequently, greater nutrient uptake efficiency (Epstein and Bloom, 2005).

Efficiency in root uptake tends to guarantee the necessary supply of nutrients destined for the shoots, a fact demonstrated by the greater production of SDW (Figure 3A) in plants of Agonandra brasiliensis, and showing the relative investment of photoassimilates produced during photosynthesis in the production of biomass in these plant compartments. Among the indices used, the Dickson Quality Index (DQI) is considered one of the best.

With outstanding responses for total dry weight and DQI, it was possible to find the best substrate for this index. The results afforded by the 18-05-09 fertiliser in substrate 1 allowed for excellent plant quality and showed the extreme importance of using Forth Cote ${ }^{\circledR}$ as the basis for these three macronutrients in management practices. According to Souza et al. (2018), this index is a good indicator of the quality of forest seedlings, as it includes robustness and the balance of seedling biomass distribution in its calculation, where the greater the value of the index, the better the quality of the seedlings.

In addition, substrate 4 , with and without the addition of SRF, promoted similar mean values for the DQI, with this index greater than 1.0 (Figure 4B), i.e. the plants of Agonandra brasiliensis achieved a similar standard of quality whether SRF was added or not, thereby reinforcing the option for lower costs in obtaining seedlings.

\section{Conclusions}

1. The use of NPK 18-05-09 formulation controlled-release fertiliser (Forth Cote ${ }^{\circledR}$ ) in a medium-sand substrate is recommended for obtaining plants of Agonandra brasiliensis of greater robustness, balance of biomass distribution and a high standard of quality.

2. In the Substrate composed of soil from the cerrado + carbonised rice husks $(\mathrm{CRH})+$ organic substrate (2:1:1), the addition of NPK 18-05-09 formulation Forth Cote ${ }^{\circledR}$ is not necessary to obtain plants of Agonandra brasiliensis of good morphological quality.

3. Substrate 3, composed of soil + CRH (3:1), with and without the addition of NPK 18-05-09 formulation (Forth $\operatorname{Cote}^{\circledR}$ ), is not recommended for producing plants of Agonandra brasiliensis, due to the slow development and reduced morphological quality of the plants. 


\section{Acknowledgments}

We thank CNPq (National Council for Scientific and Technological Development), for the Productivity and Research scholarship to the corresponding second author.

\section{References}

Bich, N. V., Mendham, D. E. K. J., Dong, T. L., Hai, V. D., \& Mohammed, C. L. (2019). Effect of residue management and fertilizer application on the productivity of a Eucalyptus hybrid and Acacia mangium planted on sloping terrain in northern Vietnam. Southern Forests: a Journal of Forest Science, 81(3), 201-212. https://doi.org/10.2989/20702620.2018.1555940

CNI. (2017). Confederação Nacional da Indústria. Florestas plantadas: oportunidades e desafios da indústria de base florestal no caminho da sustentabilidade. Confederação Nacional da Indústria, Indústria Brasileira de Árvores. Brasília, Brasil.

D'avila, F. S., Paiva, H. N., Leite, H. G., Barros, N. F., \& Leite, F. P. (2011). Effect of potassium on the hardening phase of clonal seedlings of eucalypt. Revista Árvore, 35(1), 13-19. https://doi.org/10.1590/S0100-67622011000100002

Dickson, A., Leaf, A. L., \& Hosner, J. F. (1960). Quality appraisal of white spruce and white pine seedling stock in nurseries. Forest Chronicle, 36(1), 10-13. https://doi.org/10.5558/tfc36010-1

Dutra, T. R., Massa, M. D., \& Sarmento, M. F. Q. (2016) Fertilizante de liberação lenta no crescimento e qualidade de mudas de canafístula (Peltophorum dubium). Revista Floresta, 46(4), 491-498. https://doi.org/10.5380/rf.v46i4.44570

Empresa Brasileira de Pesquisa Agropecuária (2009). Manual de análises químicas de solos, plantas e fertilizantes. Brasília, DF: Embrapa Informação Tecnológica, 86 p.

Epstein, E., \& Bloom, A. J. (2006). Mineral nutrition of plants. Sunderland: Sinauer Associates, $403 p$. http://www.scielo.br/scielo.php?script=sci_nlinks\&ref=000068\&pid=S0034-737X201400010 000500006\&lng=pt

Fermino, M. H. (2014). Substratos: composição, caracterização, e métodos de análise. Agrolivros. Guaíba, 112 p.

Ferreira, D. F. (2011). Sisvar: a computer statistical analysis system. Ciência Agrotecnologia, 35(6), 1039-1042. https://doi.org/10.1590/S1413-70542011000600001

Gomes, J. M., Couto, L., Leite, H. G., Xavier, A., \& Garcia, S. L. R. (2002). Parâmetros morfológicos na avaliação da qualidade de mudas de Eucalyptus grandis. Revista Árvore, 26(6), 655-664. https://doi.org/10.1590/S0100-67622002000600002

Holland, J. E., Hayes, R. C., Refshauge, G., Poile, G. J., Matthew, T., Newell, M. T., \& Conyers, M. K. (2019). Biomass, feed quality, mineral concentration and grain yield responses to potassium fertiliser of dual-purpose crops. New Zealand Journal of Agricultural Research, 62(4), 476-494. https://doi.org/10.1080/00288233.2018.1512505 
Menegatti, R. D., Guollo, K., Navroski, M. C., \& Vargas, O. F. (2017). Fertilizante de liberação lenta no crescimento inicial de Aspidosperma parvifolium A. DC. Sciencia Agraria Paranaensis, 16(2), 45-49.https://dx.doi.org/10.18188/1983-1471/sap.v16n1p45-49.

Menegatti, R. D., Souza, A. G., \& Bianchi, V. J. (2019). Growth and nutrient accumulation in three peach rootstocks until the grafting stage. Comunicata Scientiae, 10(4), 1-7. https://comunicatascientiae.com.br/comunicata/article/view/3211.

Messa, L. L., Froesb, J. F., Souza, C. F., \& Faez, R. (2016). Híbridos de quitosana-argila para encapsulamento e liberação sustentada do fertilizante nitrato de potássio. Química Nova, 39(10), 1215-1220. https://doi.org/10.21577/0100-4042.20160133

Ramalho, A. J., \& Zappi, D. C. (2017). Flora of the cangas of Serra dos Carajás, Pará, Brazil: Opiliaceae. Rodriguésia, 68(3), 1059-1061. https://doi.org/10.1590/2175-7860201768341

Silva, I. R., Furtini, N. A. E., Curi, N., \& Vale, F. R. (1997). Crescimento inicial de quatorze espécies florestais nativas em resposta à adubação potássica. Pesquisa Agropecuária Brasileira 32(2), 205-212. http://www.scielo.br/scielo.php?script=sci_nlinks\&ref=000135\&pid=S0100-204X199900110 $001400025 \& \operatorname{lng}=\mathrm{en}$

Smiderle, O. J., \& Souza, A. G. (2016). Production and quality of Cinnamomum zeylanicum Blume seedlings cultivated in nutrient solution. Revista Brasileira Ciências Agrárias, 2(1), 104-110. https://doi.org/10.5039/agraria.v11i2a5364

Souza, A. G., Smiderle, O. J., \& Chagas, E. A. (2018). Nutrition and accumulation of nutrients in Pochota fendleri seedlings. Revista Brasileira Ciências Agrárias, 13(3) 1-7. https://doi.org/10.5039/agraria.v13i3a5559

Souza, V. C., \& Lorenzi, H. (2012). Botânica Sistemática: guia ilustrado para identificação das famílias de Fanerógamas nativas e exóticas do Brasil, baseado em APG III. 3a ed. Instituto Plantarum, Nova Odessa, São Paulo. 768pp.

Taiz, L., Zeiger, E., Moller, I. M., \& Murphy, A. (2017). Fisiologia e desenvolvimento vegetal. 6. ed. Artmed Editora. $858 \mathrm{p}$.

Trazzi, P. A., Caldeira, M. V. W., Cusatis, A. C., \& Higa, A. R. (2014). Crescimento e nutrição de mudas de Tectona grandis produzidas em substratos orgânicos. Scientia Forestalis, Piracicaba, 42(10), 49-56. https://www.ipef.br/publicacoes/scientia/leitura.asp?Article=05\&Number=101

\section{Copyright Disclaimer}

Copyright for this article is retained by the author(s), with first publication rights granted to the journal.

This is an open-access article distributed under the terms and conditions of the Creative Commons Attribution license (http://creativecommons.org/licenses/by/4.0/). 